\title{
Prevalence of Depression among elderly living in old age homes of Kathmandu Valley and its association with Sociodemographic variants.
}

\author{
Kafle B1, Sharma VD², Ojha SP3 ${ }^{3}$ Chapagain $\mathrm{M}^{4}$, Tulachan $\mathrm{P}^{5}$, Dhungana $\mathrm{S}^{6}$ \\ 1. Resident, Dept. Of Psychiatry, Maharajgunj Medical Campus, Kathmandu 2. Prof. Dept. Of \\ Psychiatry, Maharajgunj Medical Campus, Kathmandu 3. Assoc. Prof. Dept. Of Psychiatry, \\ Maharajgunj Medical Campus, Kathmandu 4. Assoc. Prof. Dept. Of Psychiatry, Maharajgunj \\ Medical Campus, Kathmandu 5. Lecturer, Dept. Of Psychiatry, Maharajgunj Medical Campus, \\ Kathmandu 6. Teaching Assistant, Dept. Of Psychiatry, Maharajgunj Medical Campus, \\ Kathmandu.
}

E-mail *Corresponding author: kafle_bikram@hotmail.com

\begin{abstract}
Introduction: There has been a considerable increase in the numbers of older people in the world population of both developed and developing countries. The increasing elderly populations are prone to depression. Studies regarding depression among elderly, especially in old age homes is lesser in the developing countries.

Objectives: To estimate prevalence of depression among elderly living in old age homes in Kathmandu valley and its association with the socio-demographic variables, individual factors and environmental factors.

Method: It is a cross sectional study where 203 elderly people residing in old age homes of Kathmandu Valley, Nepal were selected randomly. Interview was carried out using socio-demographic tool, Geriatric Depression Scale (GDS), ICD-10 DCR, Duke social support scale, UCLA loneliness scale, and Barthel index was used.
\end{abstract}

Results: This study showed that, $47.3 \%$ of population had depression. Among them, 34.0\% had mild depression and $13.3 \%$ had severe depression. There was significant association between the prevalence of depression, health problems, satisfaction with old age home, loneliness, social support and functional disability.

Conclusion: Depressive disorder is highly prevalent among the elderly population residing in old age homes in Kathmandu Valley. This results in lowering their productivity and places burden to family and society. For this reason, concerned authorities should timely address depression in elderly people.

Keywords: Elderly people, Depression, Kathmandu

\section{INTRODUCTION}

Ageing, that begins at conception and ends at death, is a process of growing older with the flow of time in one's life. The problem of aging population is increasing like rapid fire and coming to be seen as a global burden. The elderly population is typically defined as population aged 60 years and above. The Senior Citizens Acts of Nepal 2063, defines the senior citizen as "people who are 60 years and above". According to the 2011 census of Nepal, there were 12, 78,880 elderly over 65 years old inhabitants, which constitute 4.4 percent of the total population in the country. Ageing population has been increasing in Nepal by $6.5 \%$ per annum. Life expectancy in Nepal has increased from approximately 27 years in 1951 to 66.16 years in 2011. ${ }^{1}$ Ageing population has been increasing in Nepal by $6.5 \%$ per annum. Life expectancy in Nepal has increased from approximately 27 years in 1951 to 66.16 years in 2011. 
An exceptional increase in the number and proportion of older adults in the country, rapid increase in nuclear families, and contemporary changes in psychosocial matrix and values often compel this segment of society to live alone or in old age homes. ${ }^{2}$ Ageing is an evitable developmental phenomenon bringing along a number of changes in the physical, psychological, hormonal and social conditions of individuals. Old age has been viewed as problematic period of one's life and this view is correct in the sense that the aged become increasingly dependent on other people. During this critical phase of life they may become victims of various mental problems. One of the commonest psychiatric disorders among the elderly people is depression. ${ }^{3}$

Depression in elderly lowers the productivity and increases health care financial burden to the family members. Finding out depression prevalence rate among elderly living in old age homes provides the information about the impetus we should give on mental health care. For this reason, it was imperative to study the prevalence of depression among elderly people in Nepal.

\section{MATERIAL AND METHOD}

The cross-sectional descriptive study design was used. The study areas were Social welfare center old age home, old age management / social welfare trust, Nishahayasewasadan, Divine service home, Mathatrithha old age home, Sahara care center, Siddhi shaligrambriddhashram, Dev Corner SewaSamiti, Senior citizen homes, Social Welfare Centre Old Age home (PashupatiBridhashram). Out of 411 elderly living in the above mentioned organization 203 elderly were selected. $50 \%$ of the elderly were taken from each of the organization. The elderly were selected randomly using simple random sampling method. Those who refused to give consent or refused to participate in the study and those who having speech disorder, mental retardation, psychosis, dementia were excluded. A self- designed semi structured proforma was devised to obtain the socio- demographic characteristics of the study population and other variable related tool, International Classification of Disease - 10 Diagnostic Criteria for Research (ICD-10 DCR, WHO 1992), Geriatric Depression
Scale (GDS) (Yesavage et al,1983), Revised UCLA loneliness scale:( Russelet al, 1980), DukeUNC Functional Social Support Questionnaire DUFSS: (Broadhead et al.,1988), Modified Barthel Index: (Shah et al.,1988).

applied Data were analyzed using SPSS version 16 (Chicago, Illinois, USA).

Descriptive analysis was performed, and mean, median, range were calculated. The data were explained as mean \pm standard deviation (SD) wherever suitable. Chi- square tests were for categorical data. Independent sample $t$ test, ANOVA tests were applied wherever applicable. P-value of $<0.05$ was considered significant.

\section{RESULT}

The study showed out of all 203 elderly people living in different old age homes of Kathmandu valley majority were found to be from the 75 to 84 years age group during the time of interview. $70(34.5 \%)$ cases were male, $133(65.5 \%)$ cases were female. Majority (53.2\%) cases were widow/widower. Majrity of respondents $(77.8 \%)$ were illiterate. Most of them followed Hindu religion (92.6\%), 38.9\% were farmers, and $27.6 \%$ were working as housewives before age 60. A majority of the cases $(52.2 \%)$ came from joint family and majority $(50.2 \%)$ perceived their health status as good. Majority $(71.4 \%)$ of them had some chronic illness and most of them were suffering from high blood pressure. Most of them $(61.1 \%)$ had been staying in the old age home for $1-5$ years. $88.7 \%$ cases were satisfied with the facilities of the old age home. Only $53.2 \%$ cases were receiving old age allowance. Majority had perceived low degree loneliness $(56.2 \%)$ and high social support (67.5\%). Majority of the cases (90.1\%) had slight level of dependency. Based on ICD 10 DCR $47.3 \%$ of the cases were found to be suffering from depression (table 1) among which according to GDS $34 \%$ severe and $13.3 \%$ mild depression. Depression was found to be more among those who perceived high degree loneliness, low social support, with severe level of dependency. All of these findings were found to be statistically significant too (Table 2). 
Table 1: Distribution of respondents on the basis of International classification of Disease10 Diagnostic Criteria for Research( ICD10DCR)

\begin{tabular}{|c|c|c|}
\hline $\begin{array}{l}\text { ICD -10 DCR } \\
\text { Classification }\end{array}$ & $\begin{array}{c}\text { Frequency } \\
n\end{array}$ & $\begin{array}{l}\text { Percentage } \\
\%\end{array}$ \\
\hline No depression & 107 & 52.7 \\
\hline Mild depression & 35 & 17.2 \\
\hline $\begin{array}{l}\text { Moderate depression } \\
\text { without somatic } \\
\text { syndrome }\end{array}$ & 16 & 7.9 \\
\hline $\begin{array}{l}\text { Moderate depression with } \\
\text { somatic syndrome }\end{array}$ & 18 & 8.9 \\
\hline $\begin{array}{l}\text { Severe depression } \\
\text { without psychotic } \\
\text { symptom }\end{array}$ & 27 & 13.3 \\
\hline Total & 203 & 100.0 \\
\hline
\end{tabular}

Table 2: Relationship of depression according to ICD-10 DCR with different Sociodemographic variables.

\begin{tabular}{|c|c|c|c|c|c|c|}
\hline \multicolumn{2}{|c|}{$\begin{array}{l}\text { Socio demographic } \\
\text { variables }\end{array}$} & \multicolumn{4}{|c|}{ ICD-10 DCR } & \multirow[t]{2}{*}{ P value } \\
\hline & & $\begin{array}{l}0 \\
\text { ḋ } \\
\text { İ }\end{array}$ & 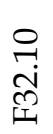 & 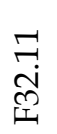 & $\begin{array}{l}\text { Nै } \\
\text { Dు }\end{array}$ & \\
\hline \multirow[t]{6}{*}{ Age } & $60-64$ & 5 & 1 & 1 & 4 & \multirow[t]{6}{*}{.221} \\
\hline & $65-69$ & 4 & 0 & 5 & 4 & \\
\hline & $70-74$ & 6 & 2 & 5 & 3 & \\
\hline & $75-79$ & 9 & 6 & 5 & 2 & \\
\hline & $80-84$ & 5 & 4 & 1 & 6 & \\
\hline & $>85$ & 6 & 3 & 1 & 8 & \\
\hline \multirow[t]{2}{*}{ Gender } & Male & 10 & 8 & 9 & 4 & \multirow[t]{2}{*}{0.62} \\
\hline & Female & 25 & 8 & 9 & 23 & \\
\hline \multirow{4}{*}{$\begin{array}{l}\text { Marital } \\
\text { status }\end{array}$} & Single & 8 & 5 & 5 & 1 & \multirow[t]{4}{*}{.528} \\
\hline & Married & 5 & 1 & 4 & 7 & \\
\hline & Separated & 4 & 2 & 2 & 2 & \\
\hline & Widow & 18 & 8 & 7 & 17 & \\
\hline
\end{tabular}

Table 3: Association of depression according to ICD-10 DCR with different other variables.

\begin{tabular}{|c|c|c|c|c|c|c|}
\hline \multicolumn{2}{|c|}{$\begin{array}{c}\text { Socio demographic } \\
\text { variables }\end{array}$} & \multicolumn{4}{|c|}{ ICD-10 DCR } & \multirow{2}{*}{$\begin{array}{l}\mathrm{P} \\
\text { value }\end{array}$} \\
\hline & & $\begin{array}{l}0 \\
\text { ì } \\
\text { ర్工 }\end{array}$ & $\begin{array}{l}\stackrel{ }{二} \\
\stackrel{N}{~} \\
\mathbb{I}\end{array}$ & 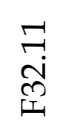 & స̃ & \\
\hline \multirow{2}{*}{$\begin{array}{l}\text { Health } \\
\text { problem }\end{array}$} & Yes & 29 & 14 & 14 & 23 & \multirow[t]{2}{*}{$0.01^{*}$} \\
\hline & No & 6 & 2 & 4 & 4 & \\
\hline \multirow{5}{*}{$\begin{array}{c}\text { Types of } \\
\text { Health } \\
\text { problem }\end{array}$} & Diabetes & 5 & 1 & 4 & 4 & \multirow[t]{5}{*}{.617} \\
\hline & $\begin{array}{l}\text { High blood } \\
\text { pressure }\end{array}$ & 6 & 3 & 3 & 3 & \\
\hline & Heart disease & 3 & 0 & 1 & 0 & \\
\hline & $\begin{array}{l}\text { Respiratory } \\
\text { problem }\end{array}$ & 7 & 7 & 3 & 6 & \\
\hline & others & 9 & 3 & 4 & 10 & \\
\hline \multirow{3}{*}{$\begin{array}{c}\text { Length of } \\
\text { stay in } \\
\text { OAH } \\
\end{array}$} & 1-5years & 23 & 7 & 13 & 8 & \multirow[t]{3}{*}{.441} \\
\hline & 5-10years & 6 & 7 & 2 & 6 & \\
\hline & $>10$ years & 6 & 2 & 3 & 3 & \\
\hline \multirow[b]{2}{*}{$\begin{array}{c}\text { Satisfacti } \\
\text { on with } \\
\text { the } \\
\text { facilities } \\
\text { of OAH }\end{array}$} & Yes & 29 & 12 & 15 & 20 & $.001^{*}$ \\
\hline & No & 6 & 4 & 3 & 7 & \\
\hline \multirow{2}{*}{$\begin{array}{l}\text { Perceived } \\
\text { loneliness } \\
\end{array}$} & low degree & 12 & 2 & 0 & 0 & \multirow[t]{2}{*}{$.000^{*}$} \\
\hline & high degree & 23 & 14 & 18 & 27 & \\
\hline \multirow{2}{*}{$\begin{array}{c}\text { Social } \\
\text { support }\end{array}$} & Low & 15 & 12 & 14 & 22 & \multirow[t]{2}{*}{$.000^{*}$} \\
\hline & high & 20 & 4 & 4 & 5 & \\
\hline \multirow{3}{*}{$\begin{array}{l}\text { Depende } \\
\text { ncy level }\end{array}$} & severe & 0 & 0 & 0 & 1 & \multirow[t]{3}{*}{$.000^{*}$} \\
\hline & moderate & 9 & 8 & 3 & 19 & \\
\hline & high & 26 & 8 & 15 & 7 & \\
\hline
\end{tabular}

The sign $\left(^{*}\right)$ indicates significant value.

\section{DISCUSSION:}

In our study, depression was found to be highly prevalent among elderly (47.3\%).This finding of our study is supported by similar studies conducted on the study of depression among geriatric population in Nepal, which showed that $53.2 \%$ of the samples experience depressive illness according to GDS. ${ }^{4}$ Similarly another study from an old age home of Chitwan showed prevalence rate of depression to be $52.73 \%$ in old-age home and $25.45 \%$ in community. ${ }^{5}$ A study conducted on prevalence of depression among elderly living in old age home in the capital city Kathmandu found it to be $47.33 \%{ }^{6}$

In another study the prevalence of depressive symptoms in elderly living in old age home was 
$59.2 \% .^{7}$ A study conducted on factors associated with depression among elderly living in old age home of Kathmandu valley, prevalence of depression was found to be $79.2 \% .^{8}$ In another study conducted on mental health problems among inhabitants of old age home in India, $37.7 \%$ were found to have depression and it was the most common mental health problem. ${ }^{2}$

The findings in the above mentioned studies could be different due to various factors starting with the different scales used to measure depression to time of conducting the study.

There was significant association between the prevalence of depression and those who reported that they had health problems. This result is supported by the study done in Nepal, which found out that there was high risk of depressive disorders among those with physical illness. ${ }^{8}$ Other studies too showed significant association between chronic illness and depression in elderly. ${ }^{9}$

There was significant association between depression and loneliness. This study finding was consistent with previous study from Nepal. ${ }^{10}$ Another study also found a significant relationship between loneliness and depression. ${ }^{11}$ Another study conducted in Lucknow India also found positive correlation between depression and loneliness. ${ }^{12}$

There was significant association between depression and lack of social support. This result is supported by the study done in Japan which showed significant increase in the risk of depression status associated with the lack of social support in Japanese elderly people in an urban community. ${ }^{13}$

There was significant association between depression and level of dependency, which included activity of daily living (ADL) measured by Barthel index. Similar results was seen in a study conducted in Asian countries significant association was found between depression and level of dependency. ${ }^{14}$ Subjects with depression had significantly lower scores for ADL. In another study ADL and perceived social support significantly predicted depression among elderly people. Higher ADL functioning and higher perceived social support predicted lower depression. ${ }^{15}$

In our study no significant association was found with other socio-demographic variables like age, gender, educational level, religion, type of family, leisure time activity, socioeconomic status and length of stay in old age home. Another study also shows depression to have significantly low correlation with sex and education. ${ }^{16}$ In a study depression was not found to be significantly associated with marital status and gender. ${ }^{9}$

Out of total respondents, $34.5 \%$ cases were male $56.34 \%$ were female. This may be due to the fact that majority of old age homes provide shelter for elderly female only. 92.6\% were Hindus, Since, Nepal was once declared a Hindu kingdom and still a majority of the population are Hindus. $^{1}$

\section{CONCLUSION:}

Depressive disorder is highly prevalent among the elderly population residing in the old age home in Kathmandu Valley. Depression is more prevalent among elderly who have chronic physical illness, poor social support, loneliness, and functional disability. Addressing these issues may contribute to improve the quality of life for the elderly and decrease burden on family, society, and the nation.

\section{REFERENCES}

1. CBS. Nepal demographic profile .(2011). Retrived from www.indexmundi.com (accessed 20 Nov 2011)

2. Tiwari, SC., Pandey, NM., Singh, I.(2012). Mental health problems among inhabitants of old age homes: A preliminary study. Indian journal of psychiatry. 54(2):144-8.

3. Singh et al, P., 2007.Psycho-social status of Senior Citizen and Related factors, Haryana India: CCS Haryna Agricultural University.

4. Khattri, J.B. \& Nepal, M.K.(2006). Study of depression among geriatric population in Nepal.Nepal Medical College journal : NMCJ, 8(4), pp.220-3.

5. Ghimire,H.,Pokharel,P.K.,Shyangwa,PM .,Baral,D.D.,Aryal,A., Mishra,A.K.(2012). Are elderly people living in old-age home, less depressed than those of community? findings from a comparative study. Journal of Chitwan Medical College, 1(2); 5-8.

6. Ranjan,S., Bhattarai, A., Dutta,M.(2013). Prevalence of depression among elderly 
people living in old agehome in the capital city Kathmandu.Health Renaissance 2013;11(3):213-218.

7. KC,P. (2013). Symptoms of depression in elderly : A comparative study on people aged 65 years and above living in an old age home and in their own home in Nepal. Retrived from http://tampub.uta.fi/handle/10024/85 058 .

8. Timalsina, R., Sherpa ,P., Dhakal, D.(2014) . Factors Associated with Depression among Elderly Living in Old Age Homes in Kathmandu Valley. Journal of institute of medicine, 36:1,9096.

9. Wijeratne, MDM, Wijerthne, SA, Wijesekara, SG, \&Wijesingha, I. Prevalence of depression among institutionalized elders in Colombo district. Student Med J. 2008; 1(1): 27-31.

10. Chalise, HN., Saito, T., Takahashi, M., Kai, I.(2007). Relationship specialization amongst sources and receivers of social support and its correlations with loneliness and subjective well-being: a cross sectional study of Nepalese older adults. Archives of gerontology and geriatrics, 44(3):299-314.

11. Singh,A.,Misra,N.(2009). Loneliness, depression and sociability in old age.Industrial psychiatry journal, 18(1):51-5.

12. Mohan,U., Gupta, A., Singh,S., Tiwari,S.(2014). Study of Depression in Geriatric Population: Old Age Home and Community in Lucknow India. Retrived from https://wce.confex.com/wce/2014/we bprogram/Paper1870.html.

13. Koizumi, Y., Awata, S., Kuriyama, S., Ohmori ,K., Hozawa, A., Seki, T., Matsuoka. H., Tsuji, I.(2005). Association between social support and depression status in the elderly: results of a 1-year community-based prospective cohort study in Japan. Psychiatry and clinical neuroscience, 59(5):563-9.

14. Wada ,T., Ishine, M., Sakagami, T., Kita, T., Okumiya, K., Mizuno, K., Rambo,
TA., Matsubayashi, K.(2005). Depression, activities of daily living, and quality of life of communitydwelling elderly in three Asian countries: Indonesia, Vietnam, and Japan. Archives of gerontology and geriatrics, 41(3):271-80.

15. Bozo, O., Toksabay, N.E., Kürüm, O.(2009). Activities of daily living, depression, and social support among elderly Turkish people. The journal of psychology, 143(2):193-205.

16. Kim, J.,Choe, M., Chae Y.(2009). Prevalence and predictor of geriatric depression in community dwelingelderly.Asian Nursing Research, 3(3):121-129. 